\title{
Esporas de microsporidios: nueva apariencia con el microscopio electrónico
}

\section{Microsporidian spore: new electron microscope appearance}

\author{
Orlando Torres-Fernández \\ Laboratorio de Microscopía Electrónica, Instituto Nacional de Salud, Bogotá, D.C., Colombia.
}

El phylum Microsporidia comprende un gran número de especies de protozoarios parásitos ubicuos en la naturaleza. Algunas tienen importancia médica como agentes causales de infecciones oportunistas en pacientes con sida. Desde las primeras imágenes de esporas de microsporidios obtenidas con el microscopio electrónico (1), su apariencia ha sido la misma que se observa en las figuras 1-2. La pared de la espora exhibe dos capas: la endospora y la exospora. La endospora es de apariencia transparente y el contenido interno de la espora (esporoplasma) no se distingue fácilmente porque es muy oscuro y se rompe con los cortes ultrafinos. Otra imagen característica es la del tubo polar que en corte transversal muestra un centro oscuro rodeado por un anillo claro. Así se ven las esporas de microsporidios de cualquier especie cuando se fijan con el método convencional de fijación con tetróxido de osmio (OsO4). Estos rasgos ultraestructurales de las esporas son muy útiles para la taxonomía del phylum Microsporidia (Microspora) (2).

Un nuevo procedimiento para la microscopía electrónica de los microsporidios, basado en la utilización de tetróxido de rutenio como fijador, revela otros detalles ultraestructurales de la pared de la espora (3). En este artículo se exhiben las primeras imágenes de las esporas completas de microsporidios procesadas con este método. Se revela el contenido de la endospora y se preserva mejor la estructura del esporoplasma. El tubo polar en corte transversal difiere del tubo polar fijado con tetróxido de osmio. El centro es claro y está rodeado por un anillo oscuro. Esta diferencia también se observa en las esporas de Polydispyrenia simulii (3). El contraste en la densidad electrónica de las capas del tubo polar podría explicarse por diferencias
The phylum Microsporidia comprises a great number of species of parasitic protozoa which are ubiquitous in nature. Some species have medical importance as causative agents of opportunistic infections in AIDS patients. Since the first electron microscope description of the microsporidian spore (1), they have been shown as in figures 1-2. The spore wall shows two layers: the endospore and the exospore. The endospore appears transparent. The internal content of the spore (sporoplasm) is not easily seen because it looks dark and the spores are often broken after thin sectioning. Moreover, sections of the polar tube show a dark central core surrounded by a clear ring. Microsporidian spores of any species are observed as described above when fixed with the conventional osmium tetroxide (OsO4) fixation method. These spore features are very useful for the taxonomy of the Microsporidia (2).

A new methodological procedure for electron microscopy makes other ultrastructural details of the spore wall visible (3). Figures $3-4$ show the first images of whole spores of Microsporidia as seen by ruthenium tetroxide (RuO4) fixation. Besides revealing the content of the endospore, the internal structure of the sporoplasm looks well preserved. The appearance of the polar tube in section differs from that of the polar tube when fixed with osmium tetroxide. The central core is clear and the surrounding ring is electron-dense. This feature was also observed in spores of Polydispyrenia simulii (3). Differences in electron density of the layers of the polar tube could be explained by different lipid composition in accordance with the fixative properties of $\mathrm{OsO} 4$ and RuO4 (3). 
en la composición de lípidos de acuerdo con las propiedades de los dos fijadores $\left(\mathrm{OsO}_{4}\right.$ y $\left.\mathrm{RuO}_{4}\right)$ (3). Estas imágenes completan la descripción de las esporas de microsporidios presentada en un artículo anterior (3).

Palabras clave: microsporidios, tetróxido de rutenio, tetróxido de osmio.
These images complement the description of the microsporidian spore presented in a previous paper (3).

Key words: Microsporidia, ruthenium tetroxide, osmium tetroxide.
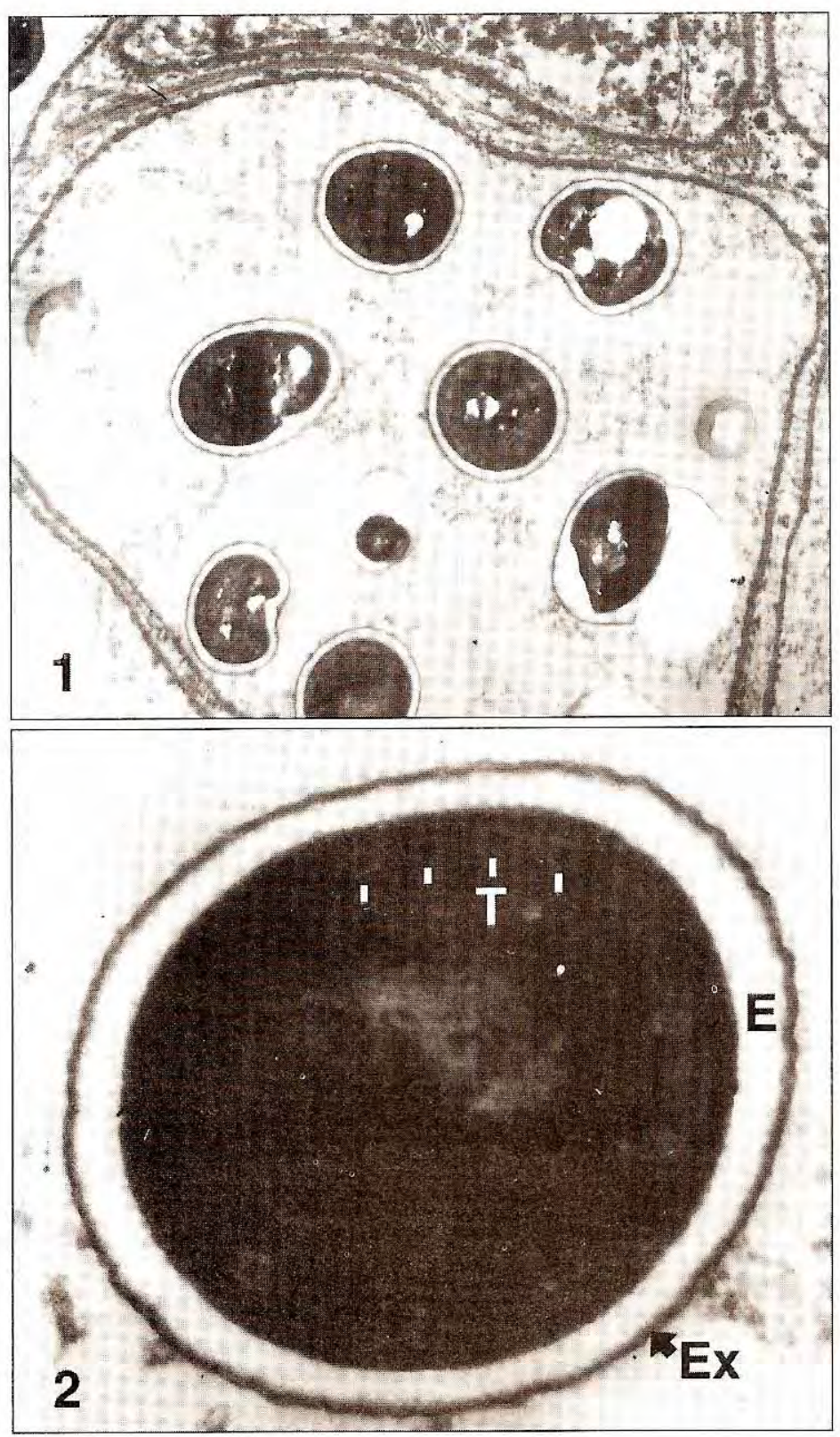

Figuras 1 y 2. Esporas de un microsporidio hallado infectando larvas de Trichoptera. Imágenes que corresponden a material fijado con tetróxido de osmio $\left(\mathrm{OsO}_{4}\right)$. $\mathrm{E}$ : endospora; Ex: exospora; T: tubo polar Figura 1: 7.630X; figura 2: $45.130 \mathrm{X}$.

Figures 1 \& 2. Spores of a microsporidium found infecting Trichoptera larvae as seen by osmium tetroxide $\left(\mathrm{OsO}_{4}\right)$ fixation.

$\mathrm{E}$ : endospore; Ex: exospore; T: polar tube Figure 1: $\times 7,630$; figure $2: \times 45,130$. 

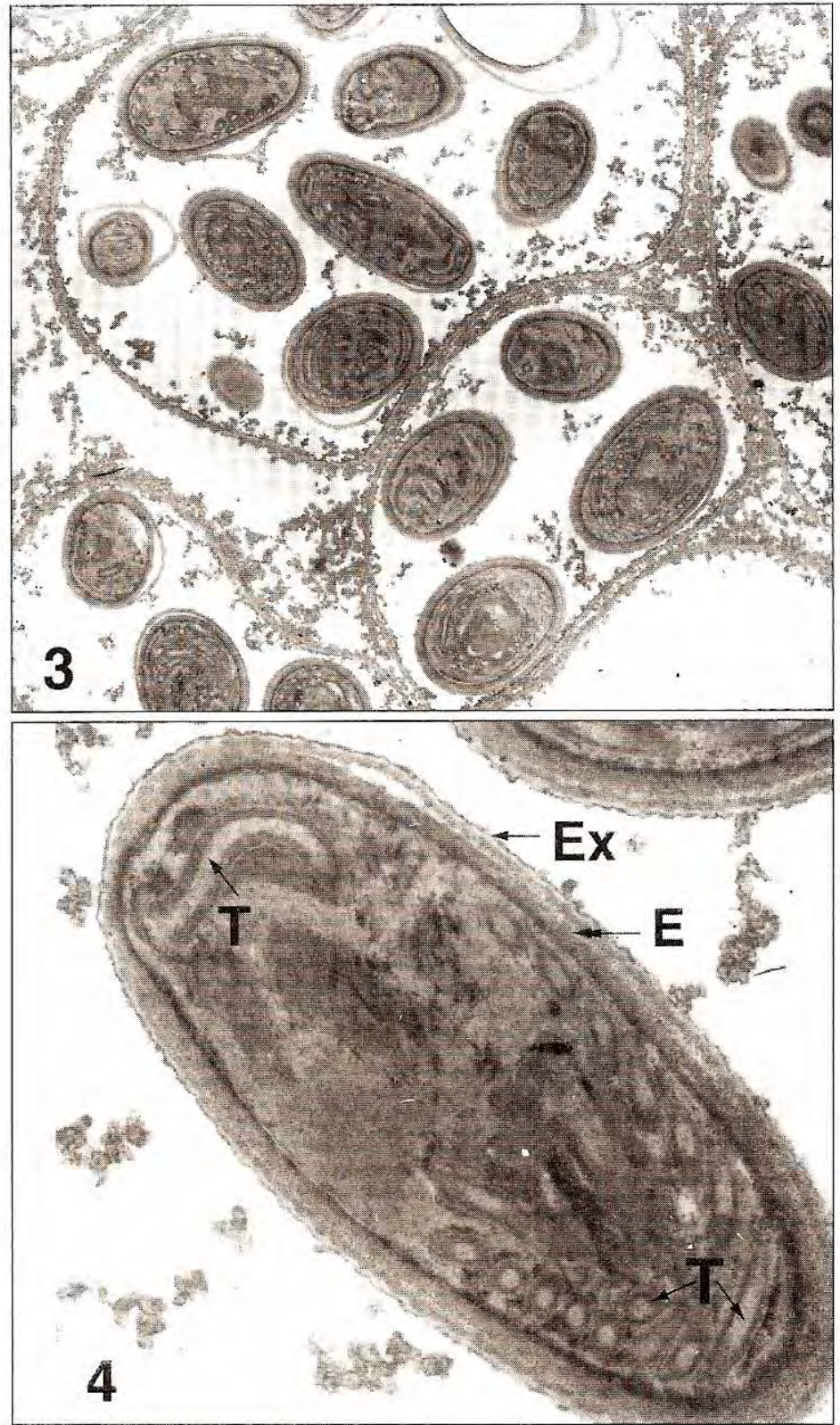

Figuras 3 y 4. Esporas de un microsporidio parásito de Trichoptera, procesadas con tetróxido de rutenio $\left(\mathrm{RuO}_{4}\right)$.

E: endospora; Ex: exospora; T: tubo polar Figura 3: 6.160X; figura 4: 25.000X.

Figures 3 \& 4. Spores of microsporidium parasite of Trichoptera as seen by ruthenium tetroxide $\left(\mathrm{RuO}_{4}\right)$ fixation.

E: endospore; Ex: exospore; T: polar tube Figure 3: X6,160; figure 4: $\times 25,000$.

\section{Referencias}

1. Huger A. Electron microscope study on the cytology of a microsporidian spore by means of ultrathin sectioning. J Insect Pathol 1960;2:84-105.

2. Larsson $\mathbf{R}$. Ultrastructure, function, and classification of microsporidia. Progr Protistol 1986;1:325-90.

3. Torres-Fernández 0 . Uitrastructural findings on microsporidia spore wall as seen by ruthenium tetroxide fixation. J Invertebr Pathol 2001;77:138-40.
Correspondencia:

Laboratorio de Microscopía Electrónica, Instituto Nacional de Salud, Avenida Calle 26 No. 51-60, Bogotá, D.C., Colombia. otorresf@hemagogus.ins.gov.co

Recibido: 11/09/01; aceptado: 19/11/01 